\title{
EMPLOYMENT CHANGES IN THE EUROPEAN ECONOMIC COMMUNITY: A SHIFT-SHARE ANALYSIS
}

\author{
Margaret A. Ray and John T. Harvey*
}

\section{INTRODUCTION}

The European Economic Community (thereafter EC) was established in 1957. Also known as the Common Market, the group was originally composed of Belgium, France, West Germany, the Netherlands, Italy, and Luxembourg. The intent of the EC was to create a free trade area in which labor, capital, and goods would move freely. Tariff barriers against member countries would be eliminated, while common external tariffs would be created against countries outside the group. In 1973, the United Kingdom, Denmark, and Ireland joined the EC. By 1986, Spain, Portugal, and Greece had joined, bringing the EC membership to 12. In 1986, the Single European Act was passed, which intended to assure that the EC's goals were met by 1992 .

Today, the EC has a population in excess of 320 million, a GNP estimated at more than $\$ 4.5$ trillion, a civilian labor force of more than $139,558,000$, and is the world's second largest mass market. Since its formation, the EC has experienced high economic growth rates, increased incomes, increased competitiveness, and increased membership. According to Hailstones and Mastrianna (1991), "By and large, the move to a single Europe is expected by its proponents to be beneficial to the European Community as a whole, as well as to individual member countries."

But as with any aggregate result, the benefits of the formation of the EC are not uniform. For example, between 1973 and 1988 the EC experienced a significant increase in employment. During this same period, eight members experienced a net growth of employment and four members experienced a net decrease in employment.

Despite its reported success, all European countries have not rushed to join the EC. Twenty-five years after its inception, nine countries in Western Europe still had not joined. Today, Austria, Finland, Iceland, Liechtenstein, Norway, Sweden, and Switzerland have their own less formal European Free Trade Association (EFTA) and are not EC members. Reasons for not joining the EC include questions regarding the distribution of benefits among EC members.

\footnotetext{
*Assistant Professor of Economics, Mary Washington College, Fredericksburg, Virginia, and Associate Professor of Economics, Texas Christian University, Ft. Worth, Texas, respectively.
} 
Recently, EFTA members began reconsidering their positions. In addition, recent changes in Eastern Europe have brought about the possibility of further expansion of existing or creation of new European free trade zones. Sentiment in some EC countries, notably France and Denmark, have shown diminished support for expanding the scope of the EC. "The recent No in Danish referendum on Maastricht's Treaty on European Union launched what will be seven lean years for the Community" (1992).

For the number of countries considering joining the EC (and those that belong but exhibit diminished support), it is important to have information about how individual countries within the EC are sharing in the aggregate gains of the Community. A joint declaration of the ministers of the EC and the EFTA countries noted that they are "aware of the growing importance of each others markets, and their responsibility of sustaining economic growth and creating employment in Western Europe." (EFTA Bulletin 1990; emphasis added). But the distribution of employment gains is also important for member countries.

As far as interregional disparities are concerned, the evidence is less clear and also, certainly, less reliable. For the period since 1970, when comparable statistics are available, interregional disparities inside the EC show no significant upward or downward trend. On the other hand, as the overall rate of unemployment rose steadily during this period, so also did the standard deviation of regional unemployment rates in the Community, which suggests a worsening of regional differences in this respect. Demographic factors were largely behind the worsening of regional differences in terms of unemployment, and these factors are expected to lead to a further deterioration of the situation in the foreseeable future. This is particularly true of Ireland, Spain and Portugal (Tsoukalis 1991, 222).

The countries that make up the EC "... are well into the process of complete economic integration" (Hailstones and Mastrianna 1991). The EC has become an established free trade zone and as such has become a relatively homogeneous economic region. While many studies have investigated the overall impact of the EC, few have focused on intraregional differences. The establishment of a single Europe allows for the study of Europe using traditional techniques of regional analysis. This study uses shift-share analysis to disaggregate employment changes in the EC to isolate differential impacts on member countries. This will provide information for current and potential EC members deciding on the appropriate level of participation. 


\section{SHIFT-SHARE ANALYSIS AND THE EC}

Shift-share analysis has frequently been used in regional economics to identify differences in income, output, or employment growth within regions (Esteban-Marquilles 1977; Merrifield 1983; Grimes and Ray 1988). More recently, shift-share analysis has been used to study international issues (Andrikopoulos, Brox, and Carvalho 1990; Sihag, Balbir, and McDonough 1989). This study conducts a shift-share analysis of the EC using employment. This technique disaggregates regional employment growth into economic components of that growth. In particular, the Esteban-Marquilles version of shift-share analysis decomposes the change in employment over time $\left({ }_{i}{ }_{j}\right)$ into four effects: aggregate growth $\left({ }_{i j}\right)$, industry mix $\left({ }^{m_{i j}}\right)$, competitive $\left({ }^{c}{ }_{i j}\right)$, and allocative $\left({ }^{a} i j\right)$. The Esteban-Marquilles technique has been criticized in the literature (Herzog and Olsen 1977), but recent examination of its structure indicates it is an appropriate formulation when identification of a region's sectors of comparative specialization is desired (Machunda 1985).

Given that several variations of the shift-share technique have been used by regional scientists and that standard definitions of terms have yet to be established, it is helpful to present the mathematical formulas and terms we use. Thus, for industrial sector $i$ in country $j$, the shift-share equation is written as

$$
d_{i j}={ }_{i j}+{ }_{i j}+{ }_{i j}^{c}+{ }_{i j}^{a} \text {. }
$$

E represents employment at the beginning of the time period, and $\mathrm{E}^{*}$ represents employment at the end of the time period. The ec subscript represents the $\mathrm{EC}$ total for the respective measures of employment.

$$
\begin{aligned}
d_{i j} & =E_{i j}^{*}-E_{i j} \\
g_{i j} & =E_{i j}\left(r_{e c}\right) \\
m_{i j} & =E_{i j}\left(r_{i, e c}-r_{e c}\right) \\
c_{i j} & =\left[E_{j}\left(E_{i, e c} / E_{e c}\right)\right]\left(r_{i j}-r_{e c}\right) \\
a_{i j} & \left.=\left[E_{i j}-\left(E_{j}\left(E_{i, e c} / E_{e c}\right)\right)\right]\left(r_{i j}-r_{i, e c}\right)_{j}-r_{i, e c}\right)
\end{aligned}
$$

Where ${ }_{i j},{ }_{i, e c}$, and ${ }^{r}$ ec reflect country and EC growth rates defined as:

$$
r_{i j}=\left(E_{i j}^{*}-E_{i j}\right) / E_{i j}
$$




$$
\begin{aligned}
& r_{i, e c}=\left(E_{i, e c}^{*}-E_{i, e c}\right) / E_{i, e c} \\
& r_{e c}=\left(E_{e c}^{*}-E_{e c}\right) / E_{e c}
\end{aligned}
$$

Shift-share analysis charges the country's industrial sectors with the rate of employment growth that is observed in the aggregate economy over the time period. The aggregate growth component measures the share of employment that the country would command if employment in the country grew at the overall EC growth rate. The difference between actual country growth, $d$, and the aggregate growth component, $\mathrm{g}$, reflects the net shift of employment within the region. The net shift is decomposed into the three remaining terms: $\mathrm{m}, \mathrm{c}$, and a.

The industry mix effect, $m$, measures the country's rate of growth in industrial section i relative to the differential between that sector's growth and the overall growth rate. The competitive effect, $c$, reflects the rate of employment growth in the country's industrial sector relative to employment growth in the same industrial sectors for the entire EC. The allocation effect, a, reflects the employment that would be observed in the country's industrial sectors if the country's structure of employment mirrored that of the EC's.

While shift-share analysis is merely a breakdown of employment changes into instructive components and cannot determine the cause of regional employment growth, it is a useful tool to help describe the conditions under which growth is occurring. A positive industry mix effect, $\mathrm{m}$, implies the country has a favorable distribution of fast growing industries, while a negative $\mathrm{m}$ indicates the country has an unfavorable distribution of slow growing industries. If the competitive effect component, $c$, is positive, this shows that industries in the country are growing faster than those same industries in the aggregate. A negative $c$ implies the country's industries are growing slower than in the EC as a whole. The allocation component, a, is interpreted as a measure of a country's degree of specialization in those sectors in which it enjoys a competitive advantage. A positive a means that the region has a "correct" specialization. That is, the region is specialized in industries in which it has a comparative advantage (Esteban-Marquilles 1977; Herzog and Olsen 1977).

\section{SHIFT-SHARE RESULTS}

The data used is from the Yearbook of Labor Statistics and represents employment in each EC country in each of nine industrial sectors. Ireland and the United Kingdom joined the EC in 1973, the year chosen as the starting point for 
this study. The first period investigated is 1973-1981 and includes the first nine countries to join the EC. After 1981, Greece, Spain, and Portugal became part of the EC. The second period investigated is from 1981-1988 and includes all 12 current members. It was necessary to end the periods examined prior to the unification of Germany.

While application of the shift-share procedure yields a wealth of information, this study is interested in the differential growth of employment within the EC. While the EC as a whole has experienced employment growth since its inception, each country within the EC has not. These results disaggregate employment growth in the EC and give insight into the impact on individual countries.

\section{Industrial Sectors within the EC}

The level of employment was examined in the following nine industrial sectors: agriculture, mining, manufacturing, electricity, construction, trade, transportation, finance, and services. Consistent and reliable data from all countries were not available for more narrowly defined industry classifications. In the period 1973-1981, the industry mix component is found to be negative for six sectors (agriculture, mining, manufacturing, electricity, construction, and transportation) and positive for the remaining three. From 1981 to 1988 , the situation is similar, with transportation joining the sectors in which the overall share of employment was rising.

According to the shift-share analysis, employment in agriculture was a declining proportion of total employment over both time periods. During 19731981, the agricultural sector in the EC shrank by 1.9 million jobs. From 1981 to 1988, agricultural employment declined by almost 2 million more. The magnitude of these results is due, in part, to the Common Agricultural Policy, or CAP. CAP was one of the first initiatives of what is now known as the EC. Article 39 of the Treaty of Rome presents five objectives of the CAP (El-Agraa 1980, 146):

1. Increase agricultural productivity.

2. Ensure a fair standard of living for the agricultural community.

3. Stabilize markets.

4. Provide certainty of supplies.

5. Ensure supplies to consumers at reasonable prices.

The EC agricultural policy has been designed to protect agriculture. "They (farmers) are a protected species, kept comfortable by societies rich enough to pay generously for their protection." EC countries transferred $\$ 142$ billion to agriculture in 1991. (The Economist 1992). 


\section{INDIVIDUAL COUNTRY RESULTS}

While general trends can be identified for each sector, the real forte of shiftshare analysis is the discovery of employment change patterns across geographic areas. In this section, those patterns are discussed for each country, grouping countries by the direction of employment changes over the two time periods. A summary of the signs of shift-share components is presented in Table 1. The complete shift-share results by employment experience are available from the authors upon request.

It appears that a country's competitive position in the EC's fast-growing industries (trade, finance, and services) is closely related to that country's net shift. In addition, the agricultural policy of the EC that provides large subsidies to farmers may be contributing to the net positive shift of countries that specialize in agriculture.

\section{Countries Experiencing Positive Employment Shifts}

Each of the positive employment shift countries had an increase in the openness of their economy within the EC. Luxembourg, The Netherlands, Italy, and West Germany experienced positive shifts in employment during both time periods. Greece, Spain and Portugal experienced positive employment shifts during the later time period. It is interesting to note that Luxembourg, The Netherlands, Italy and West Germany represent four of the five EC countries with the highest per capita GDP. Greece, Portugal and Spain have the lowest per capita GDP's ("The European Economic Community Survey" 1992).

While Luxembourg is not competitive in agriculture and has specialized accordingly, it has a competitive advantage in each of the EC's fast-growing industries. During the first period, Luxembourg had a negative $\mathrm{c}$ in trade; however, the $\mathrm{c}$ became positive during the second period. The sign of the allocation effect turned negative during the second period, indicating Luxembourg should continue to increase their specialization in finance and services to reflect their competitive advantage. Thus, Luxembourg has increased employment through specialization where they hold a competitive advantage. A relatively small EC member, Luxembourg has been able to gain by an economic structure that specializes in fastgrowing EC sectors.

The Netherlands demonstrated positive competitive effects in agriculture, trade and services during both time periods. Their competitive effect for finance became negative during the second time period; however, the negative a term indicates that they continued to specialize in the fast-growing finance sector. Traditionally an agricultural state, since World War II the Dutch have taken advantage 
TABLE 1

Signs of Net Employment Shift Terms

for EC Countries, 1973-1981 and 1981-1988

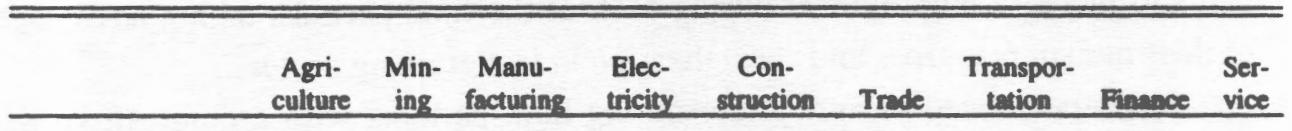

Italy

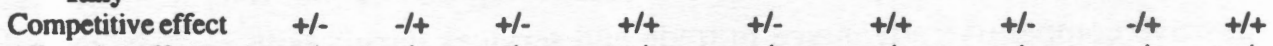

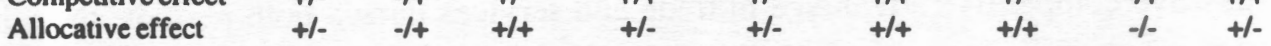

\section{Luxembourg}

Competitive effect

Allocative effect

$\begin{array}{lllllllll}-1- & -1 & -1 & +1+ & +1+ & -1+ & +1+ & +1+ & +1+ \\ +1+ & +1+ & -1+ & +/+ & +1+ & -1+ & +1+ & +1- & +1-\end{array}$

\section{Netherlands}

Competitive effect

Allocative effect

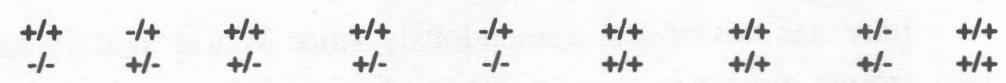

West Germany

Competitive effect

Allocative effect

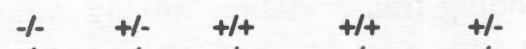

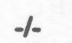

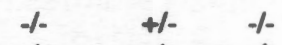

France

Competitive effect

Allocative effect

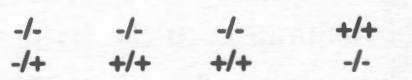

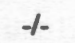

$+1+$

$+1+$

$\% \quad-1$

Ireland

Competitive effect

Allocative effect

$+1-\quad+1-\quad+1-\quad+1+$

$+1-$

$+1-\quad+1-$

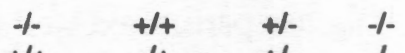

United Kingdom

Competitive effect

Allocative effect

$\begin{array}{lllllllll}-1+ & +1- & -1- & +1- & -1+ & +1- & -1 & +1+ & -1- \\ +1- & +- & +1- & -1 & +1+ & -1\end{array}$

\section{Denmark}

Competitive effect

Allocative effect

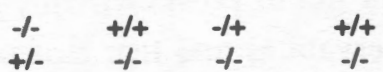

$-1+$

$-1$

$\begin{array}{lll}-1+ & -1+ & -1\end{array}$

Belgium

Competitive effect

Allocative effect

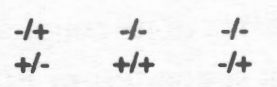

$+1-$

$+1-$

$+1+$

$-1+$

$-1+\quad-1-$

Greece*

Competitive effect

Allocative effect

Portugal*

Competitive effect

Allocative effect

\section{Spain*}

Competitive effect

Allocative effect

\begin{tabular}{l} 
Industry \\
Mix \\
\hline $1973-1981 / 1981-1985$
\end{tabular}

1973-1981/1981-1985

* Member countries after 1981. 
of their commercial culture and well-educated population by restructuring their economy to a more industrial base. This restructuring has allowed The Netherlands to increase employment during each of the time periods, taking advantage of their human resources and specialization in fast growing sectors.

Italy specialized in agriculture during both periods, with a competitive advantage during the first period that was lost during the second. Italy maintained a positive competitive advantage in trade and services during both periods, though the $a$ term indicates a need for further specialization in services in light of their competitive advantage. In finance, the competitive effect was negative during the earlier period but turned positive, and the $a$ term indicates a need for increased specialization in finance.

Italy has developed tremendously since World War II, and the benefits of that growth appear in these numbers. Great strides were made in developing the country's infrastructure, including transportation linking rural areas and power generation (Parker 1979, 107-109). In the later period, Italy continued to develop due to industrial restructuring and modernization (OECD: Italy 1989, 23). Thus, Italy has performed well as a result of maturation of the Italian economy relative to other EC countries. Starting at a relatively low base in 1973 has made it easier for Italy to post an impressive performance (OECD: Italy 1989, 23-28). Thus, Italy can expect its employment growth rate to decline as a natural progression and as a result of proposed cuts in funding for the CAP programs.

West Germany's results do not conform as well to the hypothesis that the fast-growing industries, together with agriculture, can do much to explain the employment shifts in the EC countries. Prior to West Germany joining the EC, industry and labor groups expressed reservations and fear that membership would lead to destruction of German industry. There was concern that, particularly with respect to France in coal and steel, antitrust restrictions coupled with French exports would create German unemployment. But supporters of EC membership felt that ". . many of Germany's larger enterprises would be able to benefit from the economies of scale that a market of 200 million consumers was going to offer. Some German business elites expected that Germany would become the dominant economic power of an integrated Western Europe" (Feld 1981, 41). This appears to be the case. "The economic situation plays a crucial role in motivating Bonn's policy toward the EC. The very substantial trade benefits and accompanying jobs in industry and commerce derived from the common market make it very unlikely that the Federal government would tamper with the EC" (Feld 1981, 142). West Germany seems to be doing well with its large service sector (though the competitive effect is negative), staying out of trade and agriculture, and specializing according to its competitive advantage in manufacturing. West Germany's rising productivity over this period could be reflected in these results. 
Greece, Spain, and Portugal all joined the EC for the second time period and each experienced a positive shift in employment. Each country had a positive competitive position in trade, finance and services. Greece and Portugal also had a positive competitive effect in Agriculture. These countries were competitive in each of the EC's fast-growing industries and may also have benefitted from EC agricultural policies.

The EC is the major market for all Mediterranean countries as well as a major source for imports. Prior to 1972, the EC operated with a patchwork of bilateral trade agreements with Mediterranean countries. In 1972, the Mediterranean Policy of the EC was created to give preferential treatment to Mediterranean trading partners. The political changes in Greece, Portugal, and Spain that followed allowed for their eventual entry as members in the EC. Other Mediterranean countries were not eligible for membership, and still others were eligible but were denied membership. This gives Greece, Portugal, and Spain an advantage over non-member Mediterranean states. The large agricultural component of these countries' exports has made the CAP policies particularly beneficial. Also, increased foreign investment and access to the larger market have allowed the growth of industrial sectors in these countries. Each of the three Mediterranean members has fared well under EC membership. "Unemployment in Greece appears to have remained consistently below the EC average ..." (Tsoukalis 1991, 227). Spain experienced a big economic boom coinciding with the first years of EC membership. Between 1986 and 1989, Spain registered the highest rate of economic growth among the twelve. Investment grew at a spectacular rate, and unemployment began to fall. (Tsoukalis 1991, 230). Having experienced many of the gains from entering the EC, and with the proposed reductions in CAP funding, Spain can probably expect these benefits to taper off. Tsoukalis predicts worsening regional employment differentials in the future, particularly for Spain and Portugal $(1991,222)$.

\section{Countries Experiencing Mixed Employment Shifts}

France and Ireland experienced positive employment shifts during the first period but negative shifts during the second. The United Kingdom and Denmark, on the other hand, began with a negative net shift that became positive during the second period. Increases in employment were experienced when a country's economy increased in degree of openness within the EC. A decline in the economy's EC openness was associated with a decrease in employment.

France, prior to EC membership, had a "long tradition of immobility and protectionism" (Barzanti 1965, 83). There were fears that France would not be able to compete with Germany's industrial economy. However, "the French 
economy as a whole, and the underdeveloped regions no less than the others, have shown spectacular qualities of adaptation and resilience" (Barzanti 1965, 83). This adaptation has continued throughout France's membership in the EC. The French have become a dominant political power within the group.

But the economic situation in France has been changing since the formation of the EC. The French competitive advantage in manufacturing and agriculture disappeared. France (with the second highest per capita GDP in the EC) had a superior competitive advantage in only three industries during the first period, only one of which was a fast-growing industry in the EC. During the second period, France's unemployment rate rose to 10.2 percent from 2.8 percent in 1973 . They lost their competitive advantage in finance and experienced a net decline in employment. These conditions may have been reflected in the difficulty France experienced in supporting recent advances in EC policies.

"Between 1973 and 1980, the Irish economy fared better than the EC average in terms of growth and employment creation. Exactly the opposite happened in subsequent years. Participation in the CAP has had positive budgetary and trade effects for Irish farmers ... this cornucopia did not, however, last very long as the gradual alignment of Irish farm prices to the higher EC prices more or less coincided with more determined efforts to bring CAP expenditures under control" (Tsoukalis 1991, 223)

Ireland experienced an increase in employment during the first time period and had a positive $\mathrm{c}$ for seven of the nine industries, including agriculture, trade, and finance. During the second period, they maintained a competitive advantage in only finance and experienced employment declines. Changes in CAP may lead to a significant deterioration of the Irish employment situation, as suggested by Tsoukalis $(1991,222)$.

Traditionally, Denmark has been an agricultural country. However, manufacturing (much of it related to agriculture) has grown to the point that agriculture can no longer be called dominant (Miller 1991, 122). The shift-share analysis revealed that Denmark's competitive position in every sector but mining and electricity was inferior and that the allocative effect associated with Danish sectoral employment was positive only for agriculture, construction, and trade. During the second period, employment continued to fall in Agriculture, while a gain was registered in all other sectors. In addition, every sector but agriculture and services had a positive competitive effect. Adjustment of the Danish internal economic situation lead to positive competitive positions in the second period. This resulted in the switch from employment declines in the first period to increases in the second.

From 1973 to 1981 , employment fell by 682,000 jobs in the United Kingdom. Most were lost from manufacturing, with some disappearing in agricul- 
ture, mining, construction, and transportation. The deterioration of manufacturing, combined with a decided decline in business optimism after the second oil crisis, appears to be responsible for the magnitude of the decline in employment in Britain (OECD UK 1983, 11-14).

Over the second period, employment rose by more than 1.1 million. The sectoral trends in the United Kingdom mirrored those in the EC. This turnaround was unusual not only because of the performance in the first period, but especially because overall EC conditions were less beneficial from 1981 to 1988 . The decline in manufacturing continued, but overall conditions in Britain were superior to those in the EC and thus offset the decline.

The United Kingdom had a strong competitive advantage in agriculture and finance during both periods. While not competitive in services, the United Kingdom continued to specialize in this sector over both periods. During the second period, overall economic conditions in Britain were superior to the EC average. This helps to explain the improvement in employment performance during the second period.

\section{Countries Experiencing Negative Employment Shifts}

Belgium was the only country to experience declines in employment over both periods. While Belgium has the most open economy within the EC, it also has by far the most open world economy of the EC countries. While this was an advantage when world demand was high and Belgian firms competitive, this was not the case over 1973-1981 when Belgian exports fell drastically (OECD: Belgium-Luxembourg 1982, 32-33). In light of these developments, the fall in employment during that time period is not surprising. Employment fell in agriculture, mining, manufacturing, and construction. The shift-share analysis shows Belgium's competitive position to be inferior in agriculture, mining, manufacturing, construction, trade, and services.

Over the second time period, Belgium did not fare much better. Employment fell in every sector except finance and services, and their competitive position was inferior in every industry but agriculture and services. Thus, Belgium could be losing through EC membership due to the trade restrictions placed on external trading partners and resulting retaliation against Belgian exports sent outside the EC. 


\section{v. CONCLUSIONS}

The success of free trade agreements, such as the EC, are generally evaluated using aggregated measures. There is little doubt that the EC, as a whole, has experienced increases in employment and income since its inception. But the fallacy of division tells us that what is true for the whole may not necessarily be true for each part. In order to determine in what ways and to what extent each country has been influenced by membership in the EC, it is necessary to look at disaggregated evidence.

The older-member, high per capita GNP countries and the new-member, low per capita GNP, agricultural countries each did well. These countries tended to show a competitive advantage in the EC's fast-growing industries (trade, finance, and services) and/or in the heavily subsidized agricultural sector. There is also a positive correlation between a country's degree of openness with respect to EC countries and positive employment shifts (Tsoukalis 1991, Table 7.7).

With the exception of Belgium, the remaining EC countries experienced mixed employment changes over the two time periods. Again, it appears some of the employment increases and declines could be tied to the country's competitive position in the fast growing industries.

Finally, Belgium was the only country to experience employment declines over both periods. Again, the shift-share results indicate a possible link between performance in trade, finance, services, and agriculture and employment growth.

Increased globalization of economies and the creation of free trade zones have created increasingly homogeneous international regions. As internationalization continues, the definitions of world regions change. New international administrative and functional regions, like the EC, can effectively be studied using the techniques of regional analysis.

This study applies regional analysis to an international question. This shiftshare disaggregation allows for the evaluation of employment changes in individual countries within the $\mathrm{EC}$ in order to look at differences in employment performance.

The results make it clear that each country did not share equally in the employment gains made by the EC as a whole. Each country's internal situation greatly influenced employment growth. The timing of membership and internal economic policies may also have influenced the distribution of employment gains.

The use of regional techniques is becoming increasingly appropriate to address international topics in a globalized economy. These results should be of interest to countries making decisions about participation in the EC. It appears that the Agricultural sector plays an important role in determining the distribution of EC membership benefits. However, attempts to reduce the heavy expenditures of 
the CAP program could change this. The trade and finance and services sectors also appear to be linked to EC members' success. These fast-growing industries may well continue to be associated with employment growth in EC countries. Finally, the degree of openness of the country's economy is correlated with employment gains over both time periods. It is intuitive that the more a country trades within the EC, the more it stands to benefit from membership.

\section{REFERENCES}

Adams, W.J. Restructuring the French Economy. Washington, D.C.: The Brookings Institution, 1989.

Andrikopoulos, Brox, and Carvalho. "Shift-Share Analysis and the Potential for Predicting Regional Growth Patterns: Some Evidence From Quebec, Canada." Growth and Change 21(1990): 1-10.

Barzanti, S. The Underdeveloped Areas Within the Common Market. York: Princeton University Press, 1965.

Conway, A. "Agricultural Policy." In Ireland and EC Membership Evaluated, edited by P. Keatinge, 42-59. New York: St. Martin's Press, 1991.

Demekas, D.G., K. Bartholdy, S. Gupta, L. Lipschitz, and T. Mayer. "The Effects of the Common Agricultural Policy of the European Community: A Survey of the Literature." Journal of Common Market Studies 27, no. 2 (December 1988): 111-145.

Economic Commission for Europe. Economic Survey of Europe in 1989-1990. New York: United Nations, 1990.

Economic Survey of Europe in 1982. New York: United Nations, 1983.

El-Agraa, A.M. "The Common Agricultural Policy." In The Economics of the European Community, edited by A.M. El-Agraa. New York: St. Martin's Press, 1980.

Elbaum, B., and W. Lazonick. The Decline of the British Economy. Oxford: Clarendon Press, 1986.

Esteban-Marquilles, J.M. "A Reinterpretation of Shift-Share Analysis." Regional and Urban Economics 2(1977): 249-255.

Feld, W. J. West Germany and the European Community. New York: Praeger Publishers, 1981.

Grimes. P., and M. Ray. "Right to Work Legislation and Employment Growth in the 1980's: A Shift-Share Analysis." Regional Science Perspectives 18, no. 2 (1988): 78-85. 
Hailstones, T.J., and F.V. Mastrianna. Contemporary Economic Problems and Issues. Cincinnati: South-Western Publishing Co, 1991.

Herzog, H.W., and R.J. Olsen. "Shift-Share Analysis Revisited: The Allocation Effect and the Stability of Regional Structure." Journal of Regional Science 3 (1977): 441-454.

Keatinge, P., B. Laffan, and R. O'Donnell. "Weighing up Gains and Losses." In Ireland and EC Membership Evaluated, edited by P. Keatinge, 279-291. New York: St. Martin's Press, 1991.

Lenel, H.O. "Hard-Coal Mining: A Divided and Protected Market." In The Structure of European Industry, edited by H.W. DeJong. Boston: Kluwer Academic Publishers, 1988.

Leonard D. Pocket Guide to the European Community. New York: Basil Blackwell, 1988.

Machunda, Z. "Another Look at the Additivity Properties of the Esteban-Marquilles Shift-Share Extension." Indiana University, paper presented at the Southern Regional Science Association Meetings, November 1985.

Merrifield, J. "The Role of Shift-Share in Regional Analysis." Regional Science Perspectives 13 (1983): 48-54.

Miller, Kenneth E. Denmark: A Troubled Welfare State. Boulder, Colo.: Westview Press, 1991.

OECD. Economic Survey: Belgium-Luxembourg. Paris: OECD, various years. . Economic Survey: Italy. Paris: OECD, various years. . Economic Survey: United Kingdom, Paris: OECD, various years.

"The European Economic Community Survey." The Economist. July 17, 1992: 530.

EFTA Bulletin, 1988-1990.

Panorama of EC Industries 1991-1992. Luxembourg: Office for the Official Publications of the EC.Parker, G. The Countries of Community Europe. New York: St. Martin's Press, 1979.

Pomfret, R. Mediterranean Policy of the European Community. New York: St. Martins Press, 1986.

Sihag, B.S., and C.C. McDonough. "Shift-Share Analysis: The International Dimension." Growth and Change 20(1989): 80-88.

Tsoukalis, L. The New European Economy. Oxford: Oxford University Press, 1991. 